\title{
Antithrombotic Therapy after Bioprosthetic Aortic Valve Replacement: A Therapeutic Morass
}

\author{
Anton A. Gryaznov ${ }^{a}$ b Ayman Saeyeldin ${ }^{a}$ Mohamed Abdelbaky ${ }^{a}$ \\ Mohammad A. Zafar ${ }^{\mathrm{a}}$ Maryam Tanweer ${ }^{\mathrm{a}}$ Mahnoor Imran ${ }^{\mathrm{a}}$ \\ Dimitra Papanikolaou ${ }^{a}$ Young Erben $^{\mathrm{a}}$ Julia Zefirova ${ }^{\mathrm{C}}$ \\ Bulat A. Ziganshin ${ }^{a, d}$ John A. Elefteriades ${ }^{a}$ \\ ${ }^{a}$ Aortic Institute at Yale-New Haven Hospital, Yale University School of Medicine, New Haven, CT, USA;

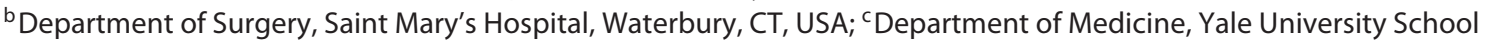 \\ of Medicine, New Haven, CT, USA; d Department of Surgical Diseases \#2, Kazan State Medical University, Kazan, Russia
}

\section{Keywords}

Anticoagulation - Adverse effects - Aortic valve replacement · Bioprosthesis · Mechanical aortic valve · Complications

\footnotetext{
Abstract

Valvular heart disease is a common pathologic condition that affects 6 million people in the United States and more than 100 million worldwide. The most common valvular disorder is aortic stenosis. Current American and European guidelines recommend surgical management for symptomatic aortic stenosis with low risk of perioperative complications and endovascular intervention for high-risk patients with multiple comorbidities. Considering the increasing volume of aortic valve replacement (AVR) with biological valves, it is very important to select the appropriate anticoagulant after surgical AVR. In this article, we review the impact of anticoagulation on immediate and remote complications after AVR.

(c) 2018 S. Karger AG, Basel
}

() 2018 S. Karger AG, Basel

E-Mail karger@karger.com

www.karger.com/crd

\section{Introduction}

Valvular heart disease (VHD) is a common pathologic condition that affects 6 million people in the United States and more than 100 million worldwide $[1,2]$. The prevalence of VHD in developed countries is likely to grow due to the dramatic increases in life expectancy and the growing number of elderly patients [3]. The most common valvular disorder is aortic stenosis. Its prevalence increases with age, that is, the prevalence rate is just $0.2 \%$ in patients aged $50-59$ years old, but increases to $9.85 \%$ in patients aged 80 years old and above.

Current American and European guidelines recommend the surgical management for all symptomatic patients with aortic stenosis $[4,5]$. In asymptomatic patients, surgery is indicated in patients with the left ventricular ejection fraction less than $50 \%$, aortic velocity $\geq 5.0 \mathrm{~m} / \mathrm{s}$ or in patients undergoing other cardiac surgeries, most commonly coronary artery bypass grafting [6]. 
Fig. 1. Algorithm for choice of prosthetic heart valves. Reprinted with permission from Rahimtoola [7]. AC, anticoagulation; AVR, aortic valve replacement; INR, international normalized ration; MVR, mitral valve replacement.

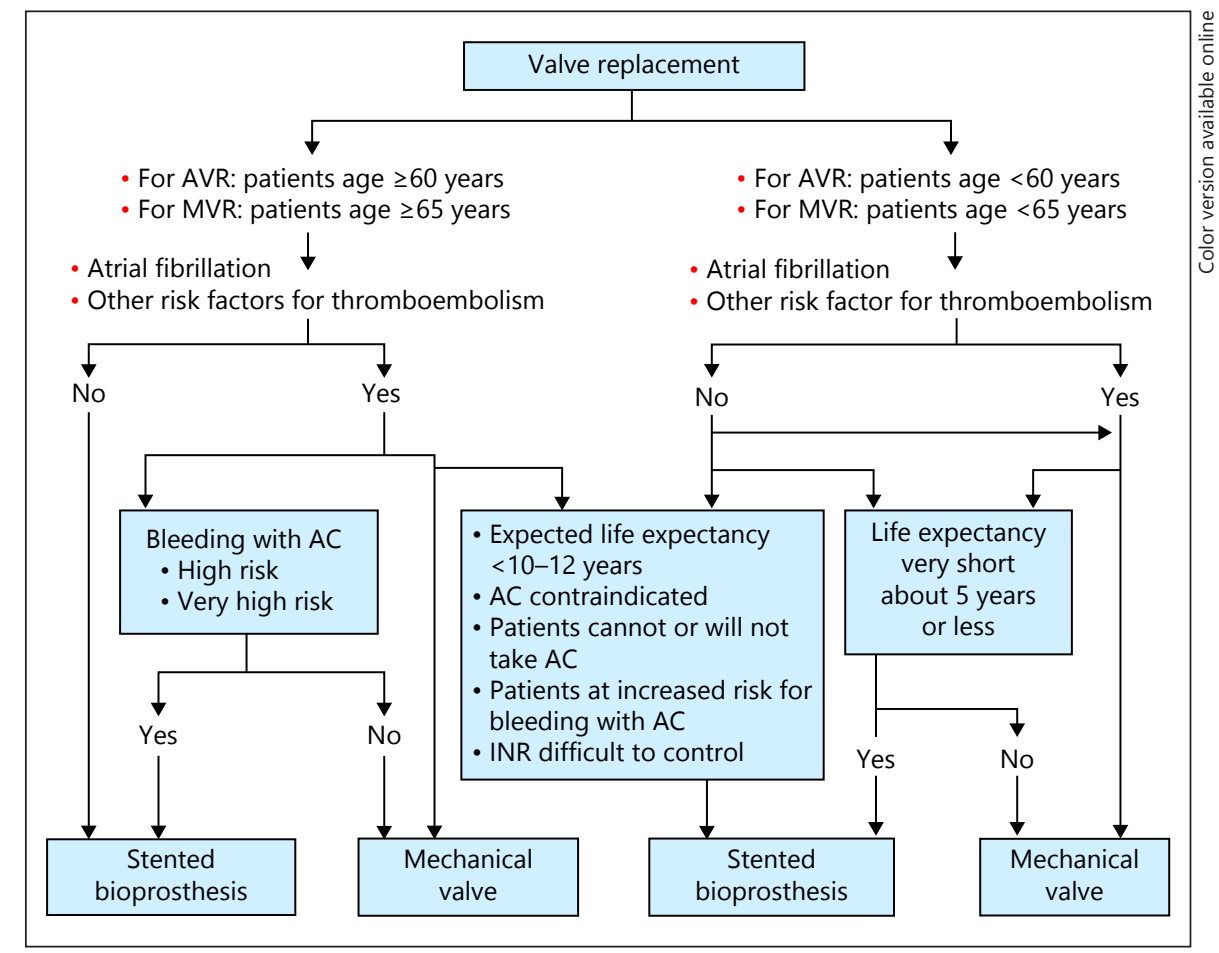

Low-risk patients usually undergo surgical aortic valve replacement (AVR), while high-risk patients proceed with transcatheter AVR (TAVR) [4, 5]. Intermediate risk patients commonly opt for surgery, though TAVR can be a reasonable alternative in selected cases [6]. Due to limited life expectancy with aortic stenosis and lack of effective medical treatment, aortic valve replacement is known to prolong life in patients with severe AS [4].

There are 2 major types of artificial aortic valves: mechanical and biological. Rahimtoola [7] suggested an algorithm to select between mechanical and biological valves (Fig. 1). Mechanical valves are more thrombogenic and require lifelong anticoagulation to prevent embolic events, thus imposing a higher risk of bleeding. Biological valves are less thrombogenic but also less durable and may lead to more frequent valve re-replacement [2]. The incidence of thrombotic events in patients who have undergone biological valve replacement is low, and American College of Cardiology/American Heart Association (ACC/AHA) Guidelines recommend a 3-month course of anticoagulation or antiplatelet therapy after intervention [4]. Despite this recommendation, the optimal regimen of anticoagulation management is uncertain [8]. Considering the increasing volume of biological AVR procedures in modern surgery [9-11], selecting the right course of anticoagulation therapy after surgical bioprosthesis is very important (Table 1).
In this article, we review the impact of anticoagulation on immediate and remote complications after aortic valve replacement as well as treatment options.

\section{Guidelines Recommendation on Anticoagulation after AVR}

The most recent guidelines were published in 2017 by ACC/AHA in the Journal of American College of Cardiology [4]. Recent American and European Guidelines contain some differences in approach to coagulation after AVR.

ACC/AHA guidelines published in the Journal of American College of Cardiology in 2017 made the following recommendations:

\section{Class II a (Moderate Recommendation)}

- Aspirin $75 \mathrm{mg}$ to $100 \mathrm{mg} /$ day is reasonable in all patients with a bioprosthetic aortic or mitral valve.

- Anticoagulation with a vitamin K antagonist (VKA) to achieve an international normalized ration (INR) of 2.5 is reasonable for at least 3 months and for as long as 6 months after surgical bioprosthetic AVR in patients at low risk of bleeding

- In patients with suspected or confirmed bioprosthetic valve thrombosis who are hemodynamically stable and 
Table 1. Antithrombotic medications which might be used after bioprosthesis

\begin{tabular}{|c|c|c|c|c|}
\hline Agent & Mechanism of action & Pharmacokinetics & Indication & Adverse reactions \\
\hline $\begin{array}{l}\text { Antiplatelet a\& } \\
\text { Aspirin } \\
81,162 \text {, and } \\
325 \mathrm{mg}\end{array}$ & $\begin{array}{l}\text { Irreversibly inhibits } \\
\text { cyclooxygenase-1 and } 2 \\
\text { (COX-1 and 2) } \\
\text { enzymes }\end{array}$ & $\begin{array}{l}\text { Onset } 1 \mathrm{~h} \\
\text { (immediaterelease) } \\
\text { Duration } 4 \mathrm{~h}-10 \text { days } \\
\text { (platelet inhibitory } \\
\text { effect) }\end{array}$ & $\begin{array}{l}\text { Secondary prevention of } \\
\text { acute MI, ischemic stroke, TIA, } \\
\text { recurrent unstable angina, } \\
\text { chronic stable angina and PVD }\end{array}$ & $\begin{array}{l}\text { Bleeding, GI } \\
\text { intolerance (other } \\
\text { side effects are } \\
\text { rare at low dosage) }\end{array}$ \\
\hline Prasugrel & $\begin{array}{l}\text { Irreversibly blocks the } \\
\text { P2Y12 component of } \\
\text { ADP receptors on the } \\
\text { platelet surface } \\
\text { (Ticagrelor is } \\
\text { reversible inhibitor) }\end{array}$ & $\begin{array}{l}\text { Onset }<30 \text { min } \\
\text { Duration } 5-9 \text { days }\end{array}$ & $\begin{array}{l}\text { Secondary prevention of acute MI, } \\
\text { ischemic stroke, TIA, } \\
\text { recurrent unstable angina, } \\
\text { chronic stable angina and PVD }\end{array}$ & $\begin{array}{l}\text { Higher risk of } \\
\text { bleeding, HTN }\end{array}$ \\
\hline Vorapaxar & $\begin{array}{l}\text { Antagonist of the } \\
\text { protease-activated } \\
\text { receptor-1. Inhibits } \\
\text { thrombin-induced } \\
\text { and thrombin receptor } \\
\text { agonist peptide-induced } \\
\text { platelet aggregation }\end{array}$ & $\begin{array}{l}\text { Onset } 1 \text { week } \\
\text { Duration } 4 \text { weeks }\end{array}$ & $\begin{array}{l}\text { Reduce thrombotic cardiovascular } \\
\text { events: cardiovascular death, MI, } \\
\text { urgent coronary revascularization in } \\
\text { patients with a history of MI or with } \\
\text { PVD }\end{array}$ & $\begin{array}{l}\text { High risk } \\
\text { of bleeding }\end{array}$ \\
\hline \multicolumn{5}{|c|}{ Anticoagulant agents } \\
\hline Warfarin & VKA & $\begin{array}{l}\text { Onset } 2-4 \text { days } \\
\text { Duration } 2-5 \text { days }\end{array}$ & $\begin{array}{l}\text { Prevent valve thrombosis and } \\
\text { thromboembolic events in } \\
\text { patients with prosthetic heart valves, } \\
\text { reduce risk of ischemic stroke and } \\
\text { systemic embolism in AF. } \\
\text { Prophylaxis and treatment } \\
\text { of DVT, PE }\end{array}$ & $\begin{array}{l}\text { Bleeding (1-3\% per } \\
\text { person-year), } \\
\text { teratogenic, } \\
\text { non-compliance, } \\
\text { drug interactions }\end{array}$ \\
\hline Dabigatran & $\begin{array}{l}\text { Reversible direct } \\
\text { thrombin inhibitor } \\
\text { (prodrug) }\end{array}$ & $\begin{array}{l}\text { Onset rapid } \\
\text { Half-life } 12-17 \mathrm{~h}\end{array}$ & $\begin{array}{l}\text { Treatment and prevention DVT, PE. } \\
\text { Reduce risk of stroke and } \\
\text { systemic embolism in AF }\end{array}$ & $\begin{array}{l}\text { Bleeding } \\
(11-19 \% \text {, major } \\
\leq 3 \%) . \mathrm{GI} \\
\text { symptoms: } \\
\text { dyspepsia, gastritis } \\
\text { like }\end{array}$ \\
\hline Edoxaban & Factor Xa inhibitor & $\begin{array}{l}\text { Onset } 1-2 \text { (peak) } \\
\text { Half-life } 10-14 \mathrm{~h}\end{array}$ & $\begin{array}{l}\text { Treatment DVT, PE. Reduce risk of } \\
\text { stroke and systemic embolism } \\
\text { in AF }\end{array}$ & $\begin{array}{l}\text { Bleeding }(22 \%) \text {, } \\
\text { vaginal }(9 \%) \\
\text { and dermal } \\
\text { hemorrhage }(6 \%)\end{array}$ \\
\hline Rivaroxaban & Factor Xa inhibitor & $\begin{array}{l}\text { Onset rapid } \\
\text { Half-life 5-9 h }\end{array}$ & $\begin{array}{l}\text { Treatment DVT, PE. Reduce risk of } \\
\text { stroke and systemic embolism } \\
\text { in AF. Thromboprophylaxis after } \\
\text { knee and hip replacement surgery }\end{array}$ & $\begin{array}{l}\text { Bleeding } \\
(5-28 \%)\end{array}$ \\
\hline
\end{tabular}

MI, myocardial infarction; AF, atrial fibrillation; DVT, deep vein thrombosis; PE, pulmonary embolism; PVD, peripheral vascular disease; VKA, vitamin K antagonist; TIA, transient ischemic attack; HTN, hypertension; ECG, electorocardiography; GI, gastrointestinal. 
have no contraindications to anticoagulation, initial treatment with a VKA is reasonable

The European Society of Cardiology and European Association of Cardio-Thoracic Surgery issued their latest guidelines in January 2018 [5]. The recommendations for anticoagulation after biological AVR are as follows:

\section{Class II a (Moderate Recommendation)}

- Aspirin alone is reasonable for the first 3 months after aortic interventions. Despite the absence of confirmatory studies, the interesting role of direct oral anticoagulants in biological prostheses is considered, especially after the third month when anticoagulation is indicated [5].

The guidelines from American College of Chest Physician Evidence-Based Clinical Practice Guidelines were published in 2012 in Chest [12]:

\section{Class 2C (Moderate Recommendation)}

- In patients with aortic bioprosthetic valves, who are in sinus rhythm and have no other indication for VKA therapy, we suggest aspirin 50-100 mg/day over VKA therapy in the first 3 months

- In patients with bioprosthetic valves in normal sinus rhythm, we suggest aspirin therapy over no aspirin therapy after 3 months postoperatively [12].

The guidelines from Canadian Cardiovascular Society from 2004 from Canadian Journal of Cardiology also recommend VKA therapy for a period of 3 months after implantation of a surgical aortic bioprothesis [13].

Thus, the Guidelines from the various societies are not consistent - reflecting a lack of definitive data in the literature.

\section{Antiplatelet Therapy for Bioprosthetic Valves}

The benefit of using antiplatelet medications in preventing thromboembolic events is still uncertain. However, there are several studies demonstrating favorable outcomes in patients with aortic biological valves [14-16]. Furthermore, some studies have shown that antiplatelet drugs produce the same outcomes as anticoagulation therapy (Table 2). For example, Colli et al. [17] in their warfarin or aspirin EPIC trial demonstrated the same incidence of postoperative ischemic events, major bleeding, and overall survival rates in both groups on warfarin (INR 2.0-3.0) or aspirin (100 mg daily) for the initial period of 3 months. The authors conclude that based on their study there is no need to start warfarin to prevent thrombosis in patients who undergo surgical biologic AVR [17]. Aramendi et al. [18] compared antiplatelet therapy with VKA and found similar results between the 2 therapies. Their prospective, multicenter, randomized trial on 193 patients (bioprosthetic AVR in 181 patients) revealed no significant difference in efficacy between 2 groups: analog of aspirin and VKA. However, an antiplatelet agent demonstrated a safer therapeutic profile and less bleeding events [18].

A recent (2017) retrospective study of 479 patients with bioprosthetic AVR compared two groups: warfarin and aspirin. At 3 months following surgical intervention, the incidence of thromboembolic and bleeding events was similar. The authors emphasized that oral anticoagulation with warfarin provided no benefit over aspirin. Therefore, they recommended aspirin as the early antithrombotic agent after biological AVR, unless warfarin is indicated for other reasons [19].

Rafiq et al. [20] conducted a randomized control trial comparing the efficacy of thromboembolic prophylaxis with warfarin-only (INR 2.0-3.0) versus oral aspirin (150 mg daily) for the first 3 months after biological aortic valve implantation. The trial demonstrated no significant advantage of warfarin over aspirin for thromboembolism prevention (6.6\% thrombotic events on warfarin vs. $7.5 \%$ on aspirin). However, bleeding events were higher in patients on warfarin compared to aspirin (5.4 vs. 1.9\%). Thus, this study illustrated a similar effect of aspirin and warfarin in patients undergoing AVR [20].

In 2013, Massel and Little [21] published a comprehensive meta-analysis of 13 randomized controlled trials with 4,122 patients. The authors compared anticoagulation therapy alone, and combined anticoagulants with an antiplatelet medication (aspirin) in patients with prosthetic aortic valves [21]. The combination of oral anticoagulation with an antiplatelet agent reduced the risk of thromboembolic events (OR 0.43, 95\% CI 0.32-0.59; $p<0.0001$ ) as well as mortality (OR $0.57,95 \%$ CI $0.42-0.78 ; p<0.0004$ ) compared to anticoagulation alone. However, the risk of major bleeding was increased in patients on combined therapy (warfarin with aspirin or dipyridamole; OR 1.58, 95\% CI 1.14-2.18; $p=0.006$ ). The meta-analysis showed benefits from adding an antiplatelet agent (aspirin or dipyridamol) to warfarin in patients with bioprosthetic valves who have comorbidities that confer, leading to high risk of thrombosis, specifically, arrhythmias, venous thromboembolism, or left ventricular dysfunction. Their study also showed similar efficacy of low- and high-dose aspirin, 100 and $500 \mathrm{mg}$ respectively [21].

A recent (2017) meta-analysis assessed the risks and benefits of using antiplatelet agents compared with VKA 
Table 2. The studies' outcomes of antithrombotic therapy after biological AVR

\begin{tabular}{|c|c|c|c|c|c|c|c|c|c|}
\hline Author & Study & $\begin{array}{l}\text { Follow/up } \\
\text { duration, } \\
\text { months }\end{array}$ & $\begin{array}{l}\text { Age, } \\
\text { years, } \\
\text { mean }\end{array}$ & Therapy & $\begin{array}{l}\text { Number } \\
\text { of patients }\end{array}$ & $\begin{array}{l}\mathrm{TE} \\
\text { (patients), } \\
\%\end{array}$ & $\begin{array}{l}\text { Hemorrhage } \\
\text { (patients), } \\
\%\end{array}$ & $\begin{array}{l}\text { Mortality } \\
\text { (patients), } \\
\%\end{array}$ & $\begin{array}{l}\text { Conclusions/ } \\
\text { recommendations }\end{array}$ \\
\hline $\begin{array}{l}\text { Brennan } \\
\text { et al. [23] }\end{array}$ & Retrospective & 3 & 77 & $\begin{array}{l}\mathrm{AC} \\
\mathrm{AP}\end{array}$ & $\begin{array}{r}8,971 \\
12,457\end{array}$ & $\begin{array}{l}0.7 \\
1.0\end{array}$ & $\begin{array}{l}2.3 \\
1.0\end{array}$ & $\begin{array}{l}3.3 \\
3.0\end{array}$ & $\begin{array}{l}\mathrm{AC}+\mathrm{AP} \text { for low bleeding } \\
\text { risk pts. AP for high } \\
\text { bleeding risk pts. }\end{array}$ \\
\hline $\begin{array}{l}\text { Colli } \\
\text { et al. [17] }\end{array}$ & Retrospective & 3 & 70 & $\begin{array}{l}\mathrm{AC} \\
\mathrm{AP}\end{array}$ & $\begin{array}{l}34 \\
35\end{array}$ & $\begin{array}{l}2.9 \\
2.8\end{array}$ & $\begin{array}{l}8.8 \\
5.7\end{array}$ & $\begin{array}{l}8.8 \\
8.5\end{array}$ & Did not support AC \\
\hline $\begin{array}{l}\text { ElBardissi } \\
\text { et al. [48] }\end{array}$ & Retrospective & 3 & 74 & $\begin{array}{l}\mathrm{AC} \\
\mathrm{AP}\end{array}$ & $\begin{array}{l}133 \\
728\end{array}$ & $\begin{array}{l}4.5 \\
5.3\end{array}$ & $\begin{array}{l}4.5 \\
2.7\end{array}$ & $\begin{array}{l}\text { ND } \\
\text { ND }\end{array}$ & $\begin{array}{l}\text { AC does not reduce TE } \\
\text { except in high-risk groups }\end{array}$ \\
\hline $\begin{array}{l}\text { Gherli } \\
\text { et al. [49] }\end{array}$ & $\begin{array}{l}\text { Prospective, } \\
\text { observational }\end{array}$ & 3 & 73 & $\begin{array}{l}\mathrm{AC} \\
\mathrm{AP}\end{array}$ & $\begin{array}{l}108 \\
141\end{array}$ & $\begin{array}{l}4.6 \\
2.1\end{array}$ & $\begin{array}{l}3.7 \\
2.1\end{array}$ & $\begin{array}{l}6.4 \\
2.8\end{array}$ & $\begin{array}{l}\text { No advantage of AC over } \\
\text { AP }\end{array}$ \\
\hline $\begin{array}{l}\text { Merie } \\
\text { et al. [30] }\end{array}$ & Retrospective & $3-24$ & 75 & $\begin{array}{l}\mathrm{AC} \\
\mathrm{AP}\end{array}$ & $\begin{array}{r}3,194 \\
881\end{array}$ & $\begin{array}{l}0.5 \\
2.7\end{array}$ & $\begin{array}{l}0.6 \\
2.4\end{array}$ & $\begin{array}{l}0.5 \\
6.9\end{array}$ & $\begin{array}{l}\text { Early discontinuation of } \\
\text { AC increases risk of TE } \\
\text { and cardiovascular death }\end{array}$ \\
\hline $\begin{array}{l}\text { Moinuddeen } \\
\text { et al. [27] }\end{array}$ & Retrospective & 3 & 74 & $\begin{array}{l}\mathrm{AC} \\
\mathrm{AP}\end{array}$ & $\begin{array}{r}109 \\
76\end{array}$ & $\begin{array}{l}2.7 \\
2.6\end{array}$ & $\begin{array}{l}9.1 \\
9.2\end{array}$ & $\begin{array}{l}\mathrm{ND} \\
\mathrm{ND}\end{array}$ & AC not necessary \\
\hline $\begin{array}{l}\text { Rafiq } \\
\text { et al. [20] }\end{array}$ & $\begin{array}{l}\text { Prospective, } \\
\text { randomized }\end{array}$ & 3 & 73 & $\begin{array}{l}\mathrm{AC} \\
\mathrm{AP}\end{array}$ & $\begin{array}{l}167 \\
161\end{array}$ & $\begin{array}{l}5.9 \\
7.4\end{array}$ & $\begin{array}{l}5.3 \\
1.8\end{array}$ & $\begin{array}{l}4.7 \\
3.7\end{array}$ & $\begin{array}{l}\text { AP effective as AC in } \\
\text { preventing TE events } \\
\text { with less bleedings }\end{array}$ \\
\hline $\begin{array}{l}\text { Sundt } \\
\text { et al. [28] }\end{array}$ & Retrospective & 3 & 76 & $\begin{array}{l}\mathrm{AC} \\
\mathrm{AP}\end{array}$ & $\begin{array}{l}624 \\
527\end{array}$ & $\begin{array}{l}2.4 \\
1.8\end{array}$ & $\begin{array}{l}1.1 \\
0.7\end{array}$ & $\begin{array}{l}\text { ND } \\
\text { ND }\end{array}$ & $\begin{array}{l}\text { AC did not protect } \\
\text { against TE } \\
\text { AC did not protect } \\
\text { against TE }\end{array}$ \\
\hline
\end{tabular}

AVR, aortic valve replacement; ND, no data; AC, anticoagulation agents; AP, antiplatelet agents (aspirin); TE, thromboembolic events. 
in patients undergoing bioprosthetic valve implantation. Researchers from Cleveland Clinic analyzed five databases yielding 2 randomized clinical trials and 12 observational studies with 31,740 patients [22]. This analysis demonstrated that between groups - VKA, antiplatelet agent, and no therapy - there were no significant differences in thromboembolic events ( 1 vs. 1.5\%, OR 0.96, 95\% CI $0.60-1.52 ; p=0.85$ ) or all-cause mortality (3.5 vs. $2.9 \%$, OR $1.48,95 \%$ CI $0.87-2.5 ; p=0.14$ ). The authors demonstrated a higher rate of major bleeding in the VKA group compared to antiplatelet agent/no therapy (2.6 vs. $1.1 \%$, OR 2.26, 95\% CI 1.67-3.05; $p<0.00001$ ). Therefore, there was no benefit of using VKA in patients after biological aortic valve replacement to prevent thromboembolic events within the first 3 months after implantation [22].

Brennan et al. [23], in a cohort study, included 25,656 patients 65 years old and older to assess the absolute risk of thromboembolic events within 3 months after aortic bioprosthesis surgery comparing warfarin and aspirin. Almost half of the patients (49\%) were discharged on aspirin only, $23 \%$ on a combination of aspirin and warfarin, and $12 \%$ on warfarin only. The aspirin group had the lowest rate of adverse effects, specifically death, embolic events, and bleeding $-3.0,1$, and $1 \%$ respectively. Patients on a combination of warfarin and aspirin had a lower incidence of embolic events and deaths but a higher risk of bleeding. Interestingly, patients on warfarin-only had similar numbers of death and embolic and bleeding events as the aspirin-only group. Although, this study has shown that bioprostheses carry a very low early risk of embolic events, the author's recommendation is to use warfarin additionally to aspirin in patients with a low risk of bleeding and aspirin-only in patients with a high risk of bleeding [23].

Considering that there is a risk of bleeding events in patients on antiplatelet agents and the lack of proof of benefit from using antiplatelet therapy in patients with biological AVR, we feel that pros and cons of routine administration of aspirin postoperatively should be investigated thoroughly, including short-term (3 months) and long-term management.

\section{Questioning Anticoagulant Therapy for Bioprosthetic Valves}

In the modern era (with durability of bioprosthetic valves approaching 20 years), the choice of a biological valve is becoming more favorable [9, 24-26]. Although ACC/AHA guideline recommend anticoagulation with VKA for 3-6 months after aortic bioprosthesis, there are several studies that suggest that anticoagulation is not necessary [14, 27-29].

Moinuddeen et al. [27], in a retrospective study, compared group of patients on oral anticoagulation therapy with warfarin versus a no-therapy group for 3 consecutive months. All 185 patients underwent surgical biological AVR and were monitored for cerebral ischemic events, bleeding, repeat intervention, and survival. Three months after surgery, no significant difference between the 2 groups was found. The authors suggest that early anticoagulation after a bioprosthesis is unnecessary [27].

Another retrospective study by Sundt et al. [28] questions the necessity of anticoagulation with warfarin after biological AVR. They identified 1,151 patients who underwent surgical AVR with or without CABG. One group of patients $(n=641)$ received anticoagulation with heparin and warfarin and the second $(n=572)$ did not receive any anticoagulation therapy. Multivariable analysis revealed that the only predictor of mortality was hypertension $(p<$ $0.0001)$. Cerebrovascular events were not prevented by warfarin $(p=0.32)$. The study demonstrated no benefit of anticoagulation within 90 days after biological AVR, with no protection against adverse neurological events [28].

Although all of the above publications present outcomes, which do not support anticoagulation after bioprosthetic AVR, the recent national study from the Copenhagen University Hospital revealed quite opposite findings. A total of 4,075 patients after biological AVR were enrolled, including 181 patients on aspirin only, 2,278 patients on warfarin only, 916 patients on warfarin and aspirin, and 700 patients who receive neither aspirin nor warfarin [30]. Patients who did not receive any treatment compared to those on anticoagulation therapy had higher thromboembolic events, rates of stroke, and cardiovascular deaths. Within 90-180 days postoperatively, for every 23 (95\% CI 14-54) patients who did not received anticoagulation with warfarin, one patient died from a cardiovascular cause. In patients on warfarin, only one death was registered for every 74 (95\% CI 27-95) patients. Warfarin decreased the incidence of thromboembolic events, stroke, and cardiovascular death within 90 and 180 days after surgical AVR [30].

Despite several guidelines from ACC/AHA [4], European Society of Cardiology and European Association of Cardio-Thoracic Surgery [5] and American College of Chest Physicians [12], anticoagulation management after bioprosthesic AVRvaries and depends on specific physician or institution practices. Brennan et al. [23] analyzed data on anticoagulation following biological AVR in 40 centers and concluded that variation of postoperative anticoagulation therapy among centers remains high [23]. 
Yet, the issue of post-AVR biological valve anticoagulation is most cogent. On the one hand, non-anticoagulated patients may be prone to serious cardioembolic events. On the other hand, anticoagulated patients are needlessly exposed to the risk of serious bleeding.

Further investigation of optimal anticoagulation strategies after biological AVR is clearly crucial. Definitive clarity is needed.

Currently the Aortic Institute at Yale University is conducting a retrospective, observational study on anticoagulation therapy after biological AVR. We have already identified 734 patients who underwent biological AVR. Preliminary analysis finds no beneficial effects of anticoagulation (whether VKA and Xa factor inhibitors or antiplatelet agents [aspirin]). We have found no significant difference in postoperative complications, including ischemic or hemorrhagic stroke, thrombosis during 3 months after surgery in patients on anticoagulation, and or on no therapy (unpublished data). This study will be completed when the remaining 1,700 patients are analyzed.

\section{Safety of Surgical AVR in the Modern Era}

Minimally invasive and endovascular procedures are reported to be safer than open heart surgery and to be associated with less pain, less bleeding, and a shorter recovery period [31]. However, recent studies revealed that surgical interventions are also very safe. In a multi-institutional retrospective review of 2,571 patients, the authors compared the outcomes of surgical AVR, minimally invasive aortic valve replacement (MIAVR) and TAVR [32]. The study demonstrated that surgical AVR, MIAVR, and TAVR had no difference in early mortality [32]. In another observational, single-center study of $1,028 \mathrm{oc}-$ togenarian patients from 2002 to 2015, the outcomes after TAVR, surgical AVR, and MIAVR were compared [33]. This 13-year study revealed that in-hospital mortality was similar among groups of surgical AVR and TAVR. Importantly, mid- and long-term survival analysis (52 months) showed that surgical intervention had significantly better long-term survival compared to the TAVR group at $12,24,36$, and 48 months survival was 86,82 , 78 , and $73 \%$, respectively, for surgical AVR versus 83,75 , 64 , and $52 \%$ survival for TAVR $(p=0.024)$ [33]. Therefore, authors concluded that the surgical approach via full sternotomy is safe and should be still offered as a treatment option even in the elderly population [33].

Another randomized, multicenter trial (PARTNER), which included 25 medical centers across the United
States, analyzed 2-year outcomes in patients who underwent either TAVR or surgical AVR [34]. The trial found that mortality and stroke rates after TAVR were similar to those after surgical AVR during the first 30 days. However, during the 2-year follow-up, patients who had a TAVR experienced paravalvular regurgitation and increased late mortality. The trial recommended using both methods as a safe management option for patients whose aortic valve needs to be replaced [34].

Transcatheter aortic valve-in-valve (ViV) implantation is becoming increasingly popular in experienced centers as an alternative to open re-do surgery in patients requiring replacement of a previously implanted aortic bioprosthesis [35]. A multinational study of 55 centers has shown an overall 1-year survival rate after ViV procedures of $83.2 \%$ (95\% CI 80.8-84.7) [36]. However, the survival rate was lower in patients with small surgical valves and aortic stenosis [36].

Although ViV interventions decreased the morbidity of reoperation, reducing recovery time and hospital stay, the technique has some serious limitations, including increased paravalvular leak [37]. ViV TAVR and surgical redo AVR both demonstrated good clinical outcomes in groups of high-risk patients and both can be chosen as an effective approach for re-intervention [38, 39]. ViV may fairly be considered an alternative approach in patients deemed high risk for redo surgical AVR [35].

\section{Conclusion}

\section{Increasing Number of AVRs}

The number of surgical AVR procedures is growing in the Western World as the prevalence of VHD is increasing with the aging of the population [9].

\section{Benefits of Biological AVR}

Biological valves are generally the preferred choice in patients older than 60 years old with contraindications to anticoagulation [24, 40-42]. Bioprostheses are less thrombogenic, leading to fewer adverse thromboembolic events. Newer biological valves are more durable and can last up to 20 years $[43,44]$ in patients $>60$ years of age and younger [45].

\section{Safety of AVR in the Modern Era}

Surgery of the aortic valve has become extraordinarily safe in the present era, even compared to minimally invasive AVR as well as TAVR [31-34]. 
The Informational "Morass" on Biological

AVR Anticoagulation

Despite the existence of multiple societal "guidelines," the data on optimal anticoagulation after biological AVR are conflicting and confusing. Definitive clarifying studies are surely needed.

\section{Conflict of Interest}

The authors declare that they have no conflicts of interest to disclose.

\section{Funding Sources}

The authors have no funding to declare.

\section{References}

1 Lung B, Vahanian A: Epidemiology of valvular heart disease in the adult. Nat Rev Cardiol 2011;8:167-172.

2 Sun JC, Davidson MJ, Lamy A, Eikelboom JW: Antithrombotic management of patients with prosthetic heart valves: current evidence and future trends. Lancet 2009;374:565-576.

3 Coffey S, Cairns BJ, Iung B: The modern epidemiology of heart valve disease. Heart 2016; 102:75-85.

4 Nishimura RA, Otto CM, Bonow RO, et al: 2017 AHA/ACC focused update of the 2014 AHA/ACC guideline for the management of patients with valvular heart disease: a report of the American College of Cardiology/ American Heart Association task force on clinical practice guidelines. J Am Coll Cardiol 2017;70:252-289.

5 Baumgartner H, Falk V, Bax JJ, et al: 2017 ESC/EACTS guidelines for the management of valvular heart disease. Rev Esp Cardiol (Engl Ed) 2018;71:110.

6 Nishimura RA, Otto CM, Bonow RO, et al: 2014 AHA/ACC guideline for the management of patients with valvular heart disease: a report of the American College of Cardiology/American Heart Association task force on practice guidelines. J Thorac Cardiovasc Surg 2014;148:e1-e132.

7 Rahimtoola SH: Choice of prosthetic heart valve in adults an update. J Am Coll Cardiol 2010;55:2413-2426.

8 Brennan JM, Alexander KP, Wallace A, et al: Patterns of anticoagulation following bioprosthetic valve implantation: observations from ANSWER. J Heart Valve Dis 2012;21:78-87.

9 Dunning J, Gao H, Chambers J, et al: Aortic valve surgery: marked increases in volume and significant decreases in mechanical valve use - an analysis of 41,227 patients over 5 years from the Society for Cardiothoracic Surgery in Great Britain and Ireland National database. J Thorac Cardiovasc Surg 2011;142:776-782.e3.

10 Brown JM, O’Brien SM, Wu C, Sikora JA, Griffith BP, Gammie JS: Isolated aortic valve replacement in North America comprising 108,687 patients in 10 years: changes in risks, valve types, and outcomes in the Society of Thoracic Surgeons National Database. J Thorac Cardiovasc Surg 2009;137:82-90.

11 Gammie JS, Sheng S, Griffith BP, et al: Trends in mitral valve surgery in the United States: results from the society of thoracic surgeons adult cardiac surgery database. Ann Thorac Surg 2009;87:1431-1437; discussion 14371439.

12 Whitlock RP, Sun JC, Fremes SE, Rubens FD, Teoh KH: Antithrombotic and thrombolytic therapy for valvular disease: antithrombotic therapy and prevention of thrombosis, 9th ed: American College of Chest Physicians Evidence-Based Clinical Practice Guidelines. Chest 2012;141(2 suppl):e576S-e600S.

13 Jamieson WR, Cartier PC, Allard M, et al: Surgical management of valvular heart disease 2004. Can J Cardiol 2004;20(suppl E): $7 \mathrm{E}-120 \mathrm{E}$.

14 Blair KL, Hatton AC, White WD, et al: Comparison of anticoagulation regimens after Carpentier-Edwards aortic or mitral valve replacement. Circulation 1994;90(5 pt 2):II214II219.

15 Heras M, Chesebro JH, Fuster V, et al: High risk of thromboemboli early after bioprosthetic cardiac valve replacement. J Am Coll Cardiol 1995;25:1111-1119.

16 Aramendi JL, Agredo J, Llorente A, Larrarte C, Pijoan J: Prevention of thromboembolism with ticlopidine shortly after valve repair or replacement with a bioprosthesis. J Heart Valve Dis 1998;7:610-614.

17 Colli A, Mestres CA, Castella M, Gherli T: Comparing warfarin to aspirin (WoA) after aortic valve replacement with the St. Jude Medical Epic heart valve bioprosthesis: results of the WoA Epic pilot trial. J Heart Valve Dis 2007;16:667-671.

18 Aramendi JI, Mestres CA, Martinez-Leon J, Campos V, Munoz G, Navas C: Triflusal versus oral anticoagulation for primary prevention of thromboembolism after bioprosthetic valve replacement (trac): prospective, randomized, co-operative trial. Eur J Cardiothorac Surg 2005;27:854-860.

19 Lee SI, Lee KS, Kim JB, et al: Early antithrombotic therapy after bioprosthetic aortic valve replacement in elderly patients: a single-center experience. Ann Thorac Cardiovasc Surg 2017;23:128-134.

20 Rafiq S, Steinbruchel DA, Lilleor NB, et al: Antithrombotic therapy after bioprosthetic aortic valve implantation: warfarin versus aspirin, a randomized controlled trial. Thromb Res 2017;150:104-110.
21 Massel DR, Little SH: Antiplatelet and anticoagulation for patients with prosthetic heart valves. Cochrane Database Syst Rev 2013; 7:CD003464.

22 Masri A, Gillinov AM, Johnston DM, et al: Anticoagulation versus antiplatelet or no therapy in patients undergoing bioprosthetic valve implantation: a systematic review and meta-analysis. Heart 2017;103:40-48.

23 Brennan JM, Edwards FH, Zhao Y, et al: Early anticoagulation of bioprosthetic aortic valves in older patients: results from the Society of Thoracic Surgeons Adult Cardiac Surgery National Database. J Am Coll Cardiol 2012;60:971-977.

24 Bourguignon T, Bouquiaux-Stablo AL, Candolfi P, et al: Very long-term outcomes of the Carpentier-Edwards Perimount valve in aortic position. Ann Thorac Surg 2015;99:831837.

25 Brown CR, Greenberg RK, Wong S, et al: Family history of aortic disease predicts disease patterns and progression and is a significant influence on management strategies for patients and their relatives. J Vasc Surg 2013; 58:573-581.

26 Isaacs AJ, Shuhaiber J, Salemi A, Isom OW, Sedrakyan A: National trends in utilization and in-hospital outcomes of mechanical versus bioprosthetic aortic valve replacements. J Thorac Cardiovasc Surg 2015;149:12621269.e3.

27 Moinuddeen K, Quin J, Shaw R, et al: Anticoagulation is unnecessary after biological aortic valve replacement. Circulation 1998;98(19 suppl):II95-II98; discussion II98-II99.

28 Sundt TM, Zehr KJ, Dearani JA, et al: Is early anticoagulation with warfarin necessary after bioprosthetic aortic valve replacement? J Thorac Cardiovasc Surg 2005;129:10241031.

29 Goldsmith I, Lip GY, Mukundan S, Rosin MD: Experience with low-dose aspirin as thromboprophylaxis for the Tissuemed porcine aortic bioprosthesis: a survey of five years' experience. J Heart Valve Dis 1998;7: 574-579.

30 Merie C, Kober L, Skov Olsen P, et al: Association of warfarin therapy duration after bioprosthetic aortic valve replacement with risk of mortality, thromboembolic complications, and bleeding. JAMA 2012;308:2118-2125. 
31 Gasparovic I, Artemiou P, Hudec V, Hulman M: Long-term outcomes following minimal invasive versus conventional aortic valve replacement: a propensity match analysis. Bratisl Lek Listy 2017;118:479-484.

32 Terwelp MD, Thourani VH, Zhao Y, et al: Minimally invasive versus transcatheter and surgical aortic valve replacement: a propensity matched study. J Heart Valve Dis 2017;26:146-154.

33 Hirji SA, Ramirez-Del Val F, Kolkailah AA, et al: Outcomes of surgical and transcatheter aortic valve replacement in the octogenarians-surgery still the gold standard? Ann Cardiothorac Surg 2017;6:453-462.

34 Kodali SK, Williams MR, Smith CR, et al: Two-year outcomes after transcatheter or surgical aortic-valve replacement. N Engl J Med 2012;366:1686-1695.

35 Reul RM, Ramchandani MK, Reardon MJ: Transcatheter aortic valve-in-valve procedure in patients with bioprosthetic structural valve deterioration. Methodist Debakey Cardiovasc J 2017; 13:132-141.

36 Dvir D, Webb JG, Bleiziffer S, et al: Transcatheter aortic valve implantation in failed bioprosthetic surgical valves. JAMA 2014;312: 162-170.

37 Nalluri N, Atti V, Munir AB, et al: Valve in valve transcatheter aortic valve implantation (ViV-TAVI) versus redo-Surgical aortic valve replacement (redo-SAVR): A systematic review and meta-analysis. J Interv Cardiol 2018, Epub ahead of print.

38 Tourmousoglou C, Rao V, Lalos S, Dougenis $\mathrm{D}$ : What is the best approach in a patient with a failed aortic bioprosthetic valve: transcatheter aortic valve replacement or redo aortic valve replacement? Interact Cardiovasc Thorac Surg 2015;20:837-843.

39 Sang SLW, Beute T, Heiser J, Berkompas D, Fanning J, Merhi W: Early outcomes for valve-in-valve transcatheter aortic valve replacement in degenerative freestyle bioprostheses. Semin Thorac Cardiovasc Surg 2017;pii:S1043-0679(17)30291-5.

40 Weber A, Noureddine H, Englberger L, et al: Ten-year comparison of pericardial tissue valves versus mechanical prostheses for aortic valve replacement in patients younger than 60 years of age. J Thorac Cardiovasc Surg 2012; 144:1075-1083.

41 Stassano P, Di Tommaso L, Monaco M, et al: Aortic valve replacement: a prospective randomized evaluation of mechanical versus biological valves in patients ages 55-70 years. J Am Coll Cardiol 2009;54:18621868.

42 Badhwar V, Ofenloch JC, Rovin JD, van Gelder HM, Jacobs JP: Noninferiority of closely monitored mechanical valves to bioprostheses overshadowed by early mortality benefit in younger patients. Ann Thorac Surg 2012;93:748-753.

43 Vesely I: The evolution of bioprosthetic heart valve design and its impact on durability. Cardiovasc Pathol 2003;12:277-286.

44 Banbury MK, Cosgrove DM 3rd, White JA, Blackstone EH, Frater RW, Okies JE: Age and valve size effect on the long-term durability of the Carpentier-Edwards aortic pericardial bioprosthesis. Ann Thorac Surg 2001;72:753757.

45 Johnston DR, Soltesz EG, Vakil N, et al: Long-term durability of bioprosthetic aortic valves: implications from 12,569 implants. Ann Thorac Surg 2015;99:12391247.

46 Berger PB, Vedamurthy D, Casale A, et al: The Risk of Thromboembolic Complications without Anticoagulation after Surgical Aortic Valve Replacement with a Bioprosthesis. J Am Coll Cardiol 2015;65:1262-359. http:// www.onlinejacc.org/content/65/10_Supplement/A2041.

47 Colli A, Verhoye JP, Heijmen R, Antunes M; ACTION Investigators: Low-dose acetyl salicylic acid versus oral anticoagulation after bioprosthetic aortic valve replacement. Final report of the ACTION registry. Int J Cardiol 2013;168:1229-1236.

48 ElBardissi AW, DiBardino DJ, Chen FY, Yamashita $\mathrm{MH}$, Cohn LH: Is early antithrombotic therapy necessary in patients with bioprosthetic aortic valves in normal sinus rhythm? J Thorac Cardiovasc Surg 2010;139: 1137-1145.

49 Gherli T, Colli A, Fragnito C, et al: Comparing warfarin with aspirin after biological aortic valve replacement: a prospective study. Circulation 2004;110:496-500.

50 Jamieson WR, Moffatt-Bruce SD, Skarsgard $\mathrm{P}$, et al: Early antithrombotic therapy for aortic valve bioprostheses: is there an indication for routine use? Ann Thorac Surg 2007;83: 549-556; discussion 556-557. 